[学会報告]

\title{
シンポジウム「がん登録等疫学研究における個人情報保護」 に参加して
}

寶珠山 務'，櫻澤 博文 ${ }^{2}$

1産業医科大学産業生態科学研究所 環境疫学教室

2産業医科大学産業生態科学研究所 作業病態学教室

要 旨：2000年 3 月16日に国立がんセンターにおいて, シンポジウム「がん登録等疫 学研究における個人情報保護」が開催され, 近く法制化が見込まれる個人情 報保護の潮流の中で，がん登録等疫学研究における個人情報利用をどう捉え るかについて検討された，国内外13名のシンポジスト，コメンテータからの 発言と総合討論の結果，わが国のがん登録を効果的に展開するために，早急 な法整備が必要なこと, がん登録等の公衆衛生活動や倫理委員会等で承認さ れた疫学研究には，患者のインフォームドコンセントを前提とせずに個人健 康情報を利用できる特例措置を設けるべきこと，および，これらの社会的措 置を含めた倫理ガイドラインをわが国でも設定すべきであること等が提案， 議論された。今後も，この種の講演会やシンポジウムが一般公開のもとで頻 繁に開催され，建設的な議論をふまえて，適切な個人情報保護制度が作られ ることが望まれる。

(2000年 5 月 15 日 受付, 2000 年 6 月 8 日 受理)

はじめに

今日の社会では, 情報ネットワーク化が著 しく進んだことで, 改めて, 情報の開示とそ の保護管理の重要性が認識されている. 医療 や保健の現場でも, 患者などデー夕提供者側 ヘカルテやレセプト情報の開示が求められる 一方で，そのプライバシーが侵害されぬよう な個人情報保護のあり方が問われている。

筆者らは, 2000年 3 月16日に, 東京・築地 の国立がんセンター国際交流会館で開催され た標記のシンポジウムに参加したので, 当日 の討論内容を含め, 今後の個人情報保護の方 向性について述べたい。

\section{シンポジウム開催までの経緯}

1999年11月, 内閣に設置された高度情報通 信社会推進本部個人情報保護検討会は，「我 が国に扔ける個人情報保護システムの在り方 について」の中間報告をまとめた。これを受 けて，総理大臣は, 2001年を目処に「個人情 報保護基本法（以下，基本法）」を制定する方 針を明らかにした。

この中間報告によれば，「我が国の個人情 報の利用と保護は, 効果的に行われる必要が ありながら，民間部門における立ち後れ(1999 年 4 月現在, 全国1529地方公共団体で個人情 報条例が制定されているが，民間側を対象に 
したものは皆無）があり，早急に検討されね ばならない」とし，「1999年の時点で,29の OECD 加盟国中 27 国までが個人情報保護関 連法律を制定していること」から，「我が国 でも早急にその関連法規の整備を行う必要が ある」こと，また，「国内法規の制定の際は， OECD 8 原則（1980年，Table 1 ）.やEU 個人 情報保護指令（1995年）を考虑し，国際的な 議論と整合性を取るべきである」ことが記載 された。

なお，同中間報告では，その個人情報とは， 「生存する個人に関する情報であって個人が 識別され得るものは基本的にすべて含まれ る」ものと定義されている.

ここで生じる問題点として, 地域がん登録
事業をはじめ，疾病登録事業，コホート研究 事業などの疫学研究では, 個人特定可能な データを用いるのが前提になっているため, OECD 8 原則の「収集制限に関する原則」や 「利用制限に関する原則」などを満たしてい ないことである．現に,1996年に策定された 「地域がん登録における情報保護ガイドライ ン」では，登録対象のがん患者本人から同意 を得ることは実質的に不可能とされている [1]。したがって，このまま前述の中間報告 の記載通りに，個人情報保護法規が制定され ると，がん登録事業などの疫学研究は，この 法律に抵触しかねないことになる。これは， 自らの研究の存続を問われることになる恐れ から，疫学関係者の不安を大きくかき立てる

Table 1. OECD 8 原則

1 収集制限に関する原則： 個人のデー夕収集には制限を設け,本人の同意を得るべきである。

2 データの正確性に関する原則：個人のデータはその利用目的に沿い, 正確, 完全, 最新 のものとするべきである.

3 目的明確化に関する原則：収集の目的は事前に明確化し, 目的変更は通知しなくてはな らない.

4 利用制限に関する原則： 個人データは，本人の同意または法規による以外，他の目的で 使用は禁止されなくてはならない。

5 保護措置に関する原則：個人デー夕は，その喪失，無権限者によるアクセス，破壊，利 用，変更または開示の危険などに対し保護措置を取らなくてはならない.

6 公開の原則： 個人データの存在が秘密になっている保管システムは存在してはいけない. その方針，業務およびシステムに関して公開されねばならない.

7 個人参加に関する原則：個人データ管理者に対し，データ主体（本人）はその情報の誤 りを訂正，削除，修正する権利を有する。

8 責任に関する原則：記録保管組織はその個人データの保管方針，業務，システムに責任 を負う。

(文献 2 より)

*OECD 8 原則の正式名称は次の通りである：「プライバシー保護と個人データの国際流通について の理事会勧告」の付属文書「プライバシー保護と個人データの国際流通についてのガイドライン」に 收録された第 2 部「国内適用に扔ける基本原則」．（原題名：Guidelines governing the protection of privacy and transborder flows of personal data; Part two. Basic principles of national application. Annex to the Recommendation of the Council of 23rd September 1980 [3].) 
こととなった。

そもそも, 個人情報保護とは, 高度に発達 した情報ネットワーク社会において，本来の 目的から逸脱した個人情報利用や漏洩を防止 することであり，がん登録など医学の発展を 目的とした疫学研究に無為に適用されるべき ではないはずである。ちなみに, 疫学研究で は個人情報を大量に扱うことから，個人のプ ライバシー保護は最優先課題として考慮され てきたことは言うまでもない [1].

こうした背景のもとで，「社会の趨勢とし ての個人情報保護」と「疫学研究における個 人情報保護」のそれぞれのあり方について， 内外の現状と今後の方向性を検討するため, 標記のシンポジゥムが開催された。

\section{本シンポジウムにおける 日本人演者の発言}

最初に, 大阪府立成人病センター調査部の 大島明氏より，わが国の地域がん登録の現状 と課題について報告された。 それによれば, 「1950年代後半に開始された我が国の地域が ん登録は, 1999年現在で34道府県市で実施さ れており，特に，がん罪患率やがん患者生存 率を把握する上で意義深い。しかしながら， 一部の地域では, 個人情報保護条例への抵触 の懸念ゆえに，がん登録事業が打ち切られた りしていることから, 欧米先進国のような国 レベルでのがん登録の法的整備が必要であ る.」とのことであった.

次いで，地域がん登録全国協議会の花井彩 氏から，今後の地域がん登録のあり方につい て報告された。それによれば，「昨年11月の 中間報告に盛り込まれた個人情報保護のあり 万は, 地域がん登録事業には相容れない部分 がある．仮に，現行のがん登録に患者の同意 を得る原則を導入したとすると, 病名告知の 問題から新たな議論を併発しかねず，結果的 に登録患者が偏る恐れが出ると考えられる。
欧米先進国の例を参考にすると，地域がん登 録事業法の制定のもとに, 国, 県, および地 域からなる全国システムが形成されており， 我が国でもこれにならって，ネットワーク事 業が展開されることが望ましい.」とのこと であった。

続いて, 厚生省大臣官房統計情報部保健統 計室の瀬上清貴氏から, 個人情報保護基本法 制定による公衆衛生の課題について報告され た。それによれば，「公衆衛生対策の構築は, 近代以降, 疫学方法論に基づいた『個人健康 情報の利活用』に伴って行われてきた. 1964 年のヘルシンキ宣言以降, 医学分野での個人 健康情報の取り扱いにはインフォームドコン セントがますます一般的になりつつある。た だし，がん登録に関しては，すべての患者に インフォームドコンセントを取ることを前提 とすることは時期尚早である。むしろ，がん 患者情報の統計作製目的での利用など，イン フォームドコンセントを前提としない個人健 康情報収集の特例的措置の必要性を国民に広 く知らせる必要がある.」とのことであった。

さらに, 中央大学法学部の堀部政男氏より, 個人情報保護検討部会中間報告について報告 された。それによれば，「個人情報の利用の 形態やその程度は分野等によって様々である ことから, 保護措置の水準は必ずしも一律で なくともよく,具体的には, 一般法として『(個 人情報保護) 基本法』, 特別法として『(各分 野ごとの）個別法』をそれぞれ制定するべき である，本中間報告では，特に，医療情報分 野は，個人情報が大量に収集，利用され，当 該個人情報の内容について機密性が高く, 漏 洩の場合の被害が大きいという特徵があると され，このことから，個人情報保護の必要性 が高く, 個別法制定のもとで個人情報保護を 行うことが重要であると記されている.」と のことであった。 


\section{本シンポジウムにおける 外国人演者の発言}

まず, IARC (International Agency for Research on Cancer）の D. M. Parkin 氏より, 機 密保護とがん登録 (原題名 “Confidentiality and cancer registries: Background, and the role of IARC”)について報告された。それによれば, 「個人の医療情報は，もちろん無為に漏洩さ れぬよう保護されるべきだが，これらを適切 な公衆衛生活動に用いること，例えば，がん 登録などは，多大な公益につながる．1980年 代以降，コンピュータを用いた個人データ取 扱いについて，社会の考え方は，必ずしも， インフォームドコンセントを得る必要はない というものに変わりつつある，そのため， IARCでは，がん登録の機密性についての ワーキンググループを設置し, 1992年にガイ ドラインをまとめたところである.」とのこ とであった。

次に，放射線影響研究所の Sheldon Wolff 氏より，米国の個人情報保護の実状（原題名

“The American point of view regarding personal information protection”)について報告された。 それによれば，「今日の米国では，1992年に成 立したがん登録修正法 (Cancer Registries Amendment Act）のもとで，多くの州でがん 登録が実施されている。ただ，個人情報保護 について連邦政府はガイドライン等を定めて いないため, 疫学研究における個人情報保護 は州により異なっているのが実状である。そ れでも，IRB(施設内倫理委員会, Institutional Review Board）を設置して, その研究の倫理 的問題を審議させること，および研究を遂行 することで対象者に与える不利益が無いか， あってもごく僅かの場合に対象者のイン フォームドコンセントを免除することは，ど の州でもほぼ同様にガイドラインに盛り込ま れている.」とのことであった。
外国人最後のシンポジストとして，オラン ダがん協会 (Danish Cancer Society) の Hans H. Storm 氏から，EU諸国での経験（原題名

"Cancer epidemiology and the EC Directive 95/ $46 / \mathrm{EC}$ of 24 October 1995 on the protection of individuals with regard to the processing of personal data and on the free movement of such data”)について報告された。それによれば, 「問題は，個々人のがん登録デー夕の開示を 巡って，個人が不利益を被るべきでないとす る権利と社会が利益を享受するべきだとする 権利とのバランスをいかに取るかである。 1990年に欧州がん登録ネットワーク（ENCR: European Network of Cancer Registries）が組織 され，EU 参加15力国でがん登録事業が開始 された。個人情報保護については, 1995年に 公布された $\mathrm{EU}$ 指令（個人デー夕の処理に対 しての個人の保護に関する指令）で規制する 一方, 疫学調査デー夕の収集, 記録, 保存な どの作業にはインフォームドコンセントが免 除されるなどの措置が取られることが明記さ れている.」とのことであった。

\section{シンポジウムでの指定発言の内容}

当日のシンポジウムでは, 上述の 7 名のシ ンポジストからの発表に続いて，法律家，疫 学研究者, 医師，一般市民，および政治家の 5 名による指定発言も行われた。

まず，法律家の立場から，慶応義塾大学法 学部の安富潔氏が，「すべての個人情報は保 護されるものであるが，保護の範囲について は個別に決定されねばならない.がん登録事 業では，扱う個人情報の性質を尊重したあり 方が求められている.」と発言した。

次に, 疫学研究者の立場から, 国立が九セ ンター研究所がん情報研究部の山口直人氏が, 「我が国では，がん登録への無理解がまだ解 消されていない。米国などのように，がん情 報ネットワークが有効に利用されるには，社 
会への貢献などについてさらに広く訴えかけ る public acceptance としての活動が必要であ る.」と発言した。

続いて，医師の立場から，日本医師会常任 理事の宮下雄平氏が，「個人健康情報をもと にした統計解析は，統計資料作製や医学研究 の上で極めて意義媣い，個人の健康情報は， 個人情報として保護される一方で，このよう な目的外利用にも活用されるべきなのではな いか.」と発言した。

さらに，一般市民の立場から，NHKの迫 田朋子氏が，「一般市民の意識としては，同 意なしに自らの診療情報は使われたくないと いうのが本音である。がん登録については， 今まで国民にほとんど知らされずに行われて きたが，その有効性を訴える前に，国民にな ぜそうせねばならなかったかを説明し，納得 してもらうのが先決ではないか. 社会のイン フォームドコンセントを得るためには，こう した『知らされていない不安』を払拭する必 要がある.」と発言した。

最後に, 政治家の立場から, 参議院議員の 武見敬三氏が，「本来，医療政策は根拠に基 づいたものでなければならないが，今までの ところ，必ずしもそうではなかった。根本の 行政機構などを見直し，法律の策定方式を改 める必要があるのではないか.」と発言した。

\section{今後の方向性について}

シンポジストおよび指定発言者からのコメ ントに引き続き，今後のがん登録のあり方に ついての総合討論が行われた，取り上げられ た議論は，「今後はがん登録について，積極 的に国民に知らせていく必要が生じている.」, 「(がん登録の成功を国民に訴えるにはどうす るべきかという問いに対する回答として）が ん登録を国民に説明する際の注意として，わ かりやすい表現で，テレビなどのメディアを 通じて行うことである。また，がん登録事業
を独立性とするのが望ましい.」,「(我が国の 個人情報保護そのものは古くからあったが， なぜ今日この話題が脚光を浴びているのかと いう問いに対する回答として）1960年代以降 に，我が国の個人情報保護についての本格的 な議論が始まり，さらに国際的な趨勢もあっ て，最近その議論が盛んになってきている。 物事には，時代が変わると問題解決が困難に なることもあるが，これはそのよい例であ る.」などであった。

締めくくりに, 本学産業生態科学研究所臨 床疫学教室の吉村健清教授加，「日本疫学 会からの個人情報保護に関連する法整備に関 する声明」として，「疫学者の学術団体であ る日本疫学会は, 対象者のプライバシー権を 尊重し, かつ有効な疫学研究を推進するため に，ガイドラインの策定と倫理審査委員会の 設置を進めてきた。個人情報保護基本法の制 定によって, 疫学研究活動が停滞することの ないように, 疫学研究における個人情報の取 扱いについては，除外規定が設けられるよう に要請する.」との発言が行われた。なお， 本シンポジウム直後の 2000 年 4 月に日本疫学 会有志会員を中心とした研究班（疫学研究に おけるインフォームドコンセントに関する研 究と倫理ガイドライン策定研究班）によりガ イドラインがまとめられた。それによると， がん登録事業の個人情報保護法での除外措置 といった特定事項には直接触れられていない が，「個人遡及可能な情報を含む既存資料を 用いる疫学研究では, 対象候補者個別にイン フォームドコンセントのプロセスを経ること が原則であり，場合によっては，その候補者 集団への説明実施, 研究倫理審査委員会での 研究妥当性審議などに替えることも可能であ る」と記載されており, 今後の疫学研究の倫 理問題を検討する際の指針になりうると思わ れる [4]. 


\section{産業保健分野の個人情報保護}

今回のシンポジウムでは, 産業医学・産業 保健分野の個人情報保護については，直接触 れられなかったものの，この分野でも労働者 個人の健康情報の取扱いなどの倫理的問題が 重要であることに変わりはない $[5]$ ，参考ま でに，その国際的コンセンサスの現状やわが 国の問題点を記したい.

この分野での個人情報保護を含めた倫理規 範の代表的なものは, 英国王室医学協会産業 医学部会の倫理ガイドライン [6], 国際労働 衛生会議（ICOH）の倫理規定 [7]，および， 国際労働機関（ILO）の労働者個人情報の保 護実施要項 [8] などであろう。これらに記 載される内容として, 個人の医療保健情報の 秘密保持については, 英国王室医学協会が「公 共の利益となることが明白な場合 [6]」など の例外規定にまで言及しているのに対し， ICOH とILOでは「国の法律または規則およ び医療関係者のための国の倫理規定の適用を 受ける [7]」といった程度に止めている。な お，英国王室医学協会のガイドラインでは， 調査研究の実施や結果の公表に伴う問題につ いて，「臨床あるいは疫学研究のいずれでも， 開始前にその計画を地域の倫理委員会に提出 し, 助言を求めるべきであり，特に，がん患 者に関する情報を取り扱う場合は，その委員 会の承認を受けねばならない[6]」と記載さ れており，今回のシンポジウムで議論された がん登録における個人情報保護の考え方とほ ぼ同じものになっている。

前述の日本疫学会研究班のガイドラインに よれば，職域での疫学研究に関する配慮事項
として,「産業医には中立性と独立性が保証 されねばならないこと」，「健診情報の帰属先 が事業所であっても従業員は研究参加の自由 が保証されねばならないこと」，および，「職 域の個人情報は従業者の不利益につながらな いように十分に保護管理されねばならないこ と」の三項目が含まれている [4]。これらは， 従来までにも，労働安全衛生制度の国際比較 研究 [9]，わが国の産業医の倫理綱領 [10] などで取り上げられてきた。確かに，前者の 目的が疫学研究の遂行であるのに対し，後者 のそれは産業保健制度の整備や同サービスの 向上などであるため, 記述上でのニュアンス や力点に若干の違いはある。しかしながら， これらに共通することとして，従業者の権利 や個人保健情報の取扱いに関する現行制度 · 手続きには，実際の社会風潮や諸外国の関連 制度に馴染まないものがあるという示唆を含 んでいることである。今後は，産業医はじめ 産業保健従事者は，常に自らの行動が倫理的 かどうかを考える姿勢が要求されるであろう。

\section{おわりに}

このシンポジウムのテーマの「個人の健康 情報保護のあり方」については，法整備に向 けての準備が開始されたところであり，わが 国における本格的な議論がようやく緒に就い たといえる。なお，今回のシンポジウム会場 は満席で立ち見も出るほどであったが，大方 の出席者は公衆衛生・疫学関係者であったよ うである，今後は，この種の講演会やシンポ ジウムが一般公開のもとで頻繁に開催され, 建設的な議論をふまえて，適切な個人情報保 護制度が作られることが望まれる。 


\section{引用 文 献}

1. 大島 明 (編) (2000)：厚生科学研究費による「がん登録等疫学研究における個人情報保護」 講演・資料集. 大阪府立成人病センター, 大阪

2. 宇野文平 (1991)：組織による健康診断と個人のプライバシー。労衝衛生 32（5）：60-64

3. http://www. oecd. org/dsti/sti/it/secur/prod/PRIV-EN. HTM

4. 厚生科研費 $(1998-99$ 年度)没学研究におけるインフォームド・コンセントに関する研究と倫 理ガイドライン策定研究班（2000）：疫学研究におけるインフォームド・コンセントに関す るガイドライン Version 1.0 (主任研究者・玉腰暁子).

5. 藤野昭宏 (1998)：生命倫理学とは何か一その考え方の基礎と限界, 生存科学への道一. 産 業医大誌 $20 ： 213-244$

6. 英国王室医学協会産業医学部会 (編)（1993）：産業医の倫理ガイダンス. 第 4 版.（土屋健 三郎, 監訳)。健康開発科学研究会, 横浜 $35 \mathrm{pp}$

7. International Commission on Occupational Health (1993)：職業保健専門家のための国際倫理規 定. (鈴木継美, 訳) 産業医学 35：233-244

8. 高田 晶(監修)（1999）：ILO労働者の健康サーベイランスのための技術・倫理ガイドライ ン/労働者個人情報の保護実施要綱. 労働基準調查会, 東京 pp 65-96

9. 前田正信, 井上正岩, 鷤尾昌一（1999）：各国の労働安全衛生関連法規·制度の国際比較一 主に産業医倫理に関して一。産衛誌 $41 ： 45-53$

10. 大久保利晃 (編) (1999)：産業医の倫理綱領 (解説版). 健康開発科学研究会, 横浜 $22 \mathrm{pp}$ 


\title{
A Report on Symposium "Protection for Personal Information in Epidemiological Research and Cancer Registry"
}

\author{
Tsutomu HOSHUYAMA', Hirofumi SAKURAZAWA ${ }^{2}$ \\ ${ }^{1}$ Department of Environmental Epidemiology, \\ ${ }^{2}$ Department of Work Systems and Health, \\ Institute of Industrial and Ecological Sciences, University of Occupational \\ and Environmental Health, Japan. Yahatanishi-ku, Kitakyushu 807-8555, Japan
}

Abstract: A symposium on protection of personal information in epidemiological research and the compilation of a cancer registry was held at the National Cancer Center, Japan, on March 16, 2000. Participants discussed the use of personal health information in epidemiological research activities such as the compiling of a cancer registry to protect personal information. Legislation in Japan is pending in the near future. A total of thirteen domestic and foreign speakers and commentators shared opinions from various viewpoints and discussed the issue. It was proposed that protection regarding personal information should be legislated as soon as possible for the development of a cancer registry; patients could be exempted from informed consent for utilization of personal health information, in particular, in public health activities such as the compilation of a cancer registry and epidemiological research with the approval of an ethics review board; ethical guidelines including these steps should be established in Japan. An appropriate system of protection of personal information should be established through constructive discussion at frequent meetings and symposia which are open to the citizenry.

Key words: epidemiology, cancer registry, informed consent, personal information, privacy

J UOEH $22(3): 283-290(2000)$ 